\title{
Finding common ground: exploring synergies between degrowth and environmental justice in Chiapas, Mexico
}

\author{
Jonathan Otto ${ }^{1}$ \\ Miami University, USA
}

\begin{abstract}
In this article I explore potential synergies between degrowth and environmental justice movements, with a focus on their shared goal of inclusivity. I turn to the case of the contentious San Cristóbal-Palenque highway project in Mexico's southernmost state, Chiapas, and highlight the ability of such intersections to speak to the concerns of protesters of the initiative. Since the mid-1990s, critics of market-based development in Chiapas have provided a sustained critique of the Mexican government's growth-oriented development agenda and related conditions of poverty and inequality in the state. These critics mobilized in 2009 and 2014 to protest the construction of a mega-highway designed to enhance agribusiness and tourism in the region. This opposition finds many points of overlap with perspectives of degrowth proponents in its critique of growthbased development, and yet is rooted in a unique socio-political and historical context. Given the situated nature of this opposition, I argue that a synergistic approach that takes into account the thinking of degrowth proponents and environmental justice advocates is needed, to address the concerns of highway protesters in Chiapas whose critiques of a growth society emerged from its negative effects to which they are disproportionately exposed.
\end{abstract}

Key Words: Degrowth, environmental justice, contestation, Mexico

\section{Résumé}

Dans cet article, je explore les synergies potentielles entre le décroissement et les mouvements de justice environnementale, en mettant l'accent sur leur objectif commun d'inclusivité. Je me tourne vers le cas litigieux du projet de la route San Cristóbal-Palenque dans l'état le plus au sud du Mexique, le Chiapas, tout en mettant en évidence la capacité de ces intersections qui donnent une voix aux préoccupations des manifestants issues de cette initiative. Depuis la moitié des années 1990, les opposants du développement basé sur le marché au Chiapas apportent une critique soutenue du programme de développement axé sur la croissance du gouvernement mexicain, et des conditions liées à la pauvreté et l'inégalité de l'État. Ces opposants se sont mobilisés entre 2009 et 2014 pour protester contre la construction de la méga-autoroute destinée à soutenir l'industrie agricole et le tourisme dans cette région. Cette opposition trouve de nombreux points de chevauchement avec les perspectives des partisans du décroissement dans la critique du développement axé sur la croissance, mais elle continue d' être enracinée dans un contexte sociopolitique et historique particulier. Étant donné le caractère localisé de cette opposition, je soutiens qu'une approche synergique qui tient en compte la pensée des partisans du décroissement et des défenseurs de la justice environnementale est nécessaire pour répondre aux préoccupations des manifestants routiers au Chiapas, là où les critiques d'une société de croissance ont fait surgir des effets négatifs qui ont disproportionnellement été exposés.

Mots clés: Décroissance, justice environnementale, contestation, Mexique

\section{Resumen}

En este artículo exploro las sinergias posibles entre los movimientos relacionados al decrecimiento y los de justicia ambiental, con un énfasis en su objetivo en común, la inclusión. Me referiré al caso del polémico

\footnotetext{
${ }^{1}$ Dr. Jonathan Otto, Visiting Assistant Professor, International Studies, Miami University, USA. Email: ottojj3 "at" gmail.com. Many thanks to friends and collaborators who generously provided me with shelter and transportation, who encouraged me to conduct this research, and who, in countless ways, facilitated the conversations that informed this article. Thank you also to Susan Paulson and Casey Walsh who provided generous and insightful feedback on earlier versions of this article. This is the fourth article in Lisa L. Gezon and Susan Paulson (eds.) 2017. "Degrowth, culture and power", Special Section of the Journal of Political Ecology, 24: 425-666.
} 
proyecto de la autopista San Cristóbal-Palenque, en el estado de Chiapas, México y resaltaré la capacidad de tales intersecciones para expresar las preocupaciones de los manifestantes en contra de la iniciativa. Desde mediados de la década de 1990 en Chiapas, los críticos de un desarrollo basado en el mercado han proporcionado una crítica al gobierno Méxican tanto por su agenda de desarrollo, ya que está orientada al crecimiento, como por las condiciones de pobreza y desigualdad vinculadas a esta. Estos críticos se movilizaron en 2009 y 2014 para protestar la construcción de la mega-autopista destinada a mejorar la agroindustria y el turismo en la región. Esta oposición tiene muchos puntos en común con las perspectivas de decrecimiento en la crítica al desarrollo, y sin embargo está arraigada en un contexto socio-político e histórico único. Dado el carácter situado de esta oposición, argumento que un enfoque sinérgico que tome en cuenta el pensamiento de los defensores del decrecimiento y los defensores de la justicia ambiental es necesario para abordar las preocupaciones de los manifestantes de carreteras en Chiapas, cuyas críticas de una sociedad de crecimiento surgieron de los efectos negativos a lo que están expuestos desproporcionadamente.

Palabras clave: Decrecimiento, justicia ambiental, contestación, México

\section{Introduction}

Ideas about degrowth have gained momentum in recent years as recognition of the ecologically untenable nature of a growth society has increased. Degrowth has been described as a political slogan and a movement, calling into question the hegemonic notion that a society's well-being is rooted in continuously expanding production and consumption (Latouche 2009). The main objects of critique for degrowth proponents include: capitalism, an economic system that values and depends on continued growth; Gross Domestic Product (GDP), a measure of a given society's well-being that narrowly takes economic growth as its main focal point; and commodification, a process whereby modes of expanding production and consumption extend into new frontiers (Kallis et al. 2015). Conversely, as Kallis et al. point out, activists operating under the banner of degrowth valorize non-growth oriented aspects of a given society such as care, the commons, and cooperatives that are either ignored or undervalued from a growth perspective, but which they argue are central to a collective well-being.

Degrowth perspectives, which were preceded by influential works such as the report of the Club of Rome in 1972 and Romanian economist Nicolas Georgescu-Roegen, have been adopted by anti-globalization and social movements as well as mainstream political parties in Europe. Moreover, despite the fact that the slogan/movement is fairly young, degrowth critiques have been incorporated into a range of scholarly analysis. Originating in France as decroissance, such analyses focused initially on the issue of resource limits. However, in the early-2000s, the idea of decroissance began to expand geographically to Italy (decrescita) and Spain (decrecimiento), particularly through the Institute of Environmental Science and Technology (ICTA), and from there to Latin America (Kallis et al. 2015). While the term expanded geographically in use, it also grew to include of a broader set of thematic foci, thus making degrowth difficult to represent in the singular. In Mexico City, for instance, degrowth proponents, drawing on the work of Ivan Illich, began in 2007 to voice concerns about a broad set of issues ranging from the negative environmental and social effects of growth-based development (including its so-called "sustainable development" variants) to continued broadbased dependence on fossil fuels. In doing so, they began to invoke the concept of degrowth to frame discussions about issues that had long been of concern in the country, particularly in Mexico's southernmost state, Chiapas - issues that have been foundational in the evolution of thinking about degrowth.

In Chiapas the Zapatistas - a largely Mayan group - have provided a sustained and dynamic critique of the Mexican Federal Government and Chiapas State Government's growth-oriented development agenda, which they see as contributing to, rather than alleviating, persistent conditions of poverty and inequality in the state. The Zapatistas first made their presence known in 1994 with a violent uprising that coincided with the January 1 advent of the North American Free Trade Agreement (NAFTA). Arguing that NAFTA would only serve transnational interests at the expense of local well-being, they have since garnered broad support among activists across the country and the world. Following the 1994 uprising, the Zapatistas transitioned into a more non-violent mode of resistance, but their object of critique has remained the same: namely, the Mexican 
state's attempt to convert Chiapas into a neoliberal export economy defined by the extraction of the state's natural resources and the commodification of its cultural wealth.

In Chiapas, criticism of growth-oriented development has recently centered around the San CristobalPalenque Highway initiative, a project that emerged twice, first in 2009 and again in 2014. The goal of the highway was to spawn economic development by expanding agribusiness and tourism across the eastern portion of the state. However, despite the proposed benefits of the project, a diverse network of actors that included Zapatista communities, nongovernmental organizations (NGOs), non-Zapatista Mayan and mestizo communities, academics, and religious figures, argued that the highway would not be beneficial to them, but would instead lead to local environmental destruction and social division.

The anti-highway protesters found key points of overlap with degrowth advocates in Mexico and elsewhere, although unique local characteristics of their activism persisted. The main point of overlap was related to their shared concern for the environmentally and socially destructive outcomes of growth-based development. Yet for many highway protesters, such anxiety was also linked to their unique lived history of oppression and exclusion by the Mexican state and transnational actors - an experience that is shared by indigenous people across Mexico and Latin America. In fact, as becomes clear in this article, opposition to the highway project was often rooted in local concerns about power, history, and Mayan rights to and relationships with the natural environment.

In this article, I show how traditions of scholarship and activism in environmental justice, political ecology and degrowth work together to illuminate the motivations and experiences of activists in Chiapas, and the uniquely local characteristics of their anti-highway activism. While degrowth thinking has been informed by environmental justice movements over time, I argue specifically that this integral approach takes into account issues of procedural and distributional justice that lie at the heart of the highway protests, considers how such injustices are produced through the interactions of actors and policies that operate at multiple scales, and recognizes the historical dimensions of justice claims.

In the introduction to this Special Section, Susan Paulson (2017) notes that degrowth perspectives are lived by a network of actors that operate across space, that occupy multiple cultural and political terrains, and that come together to support alternative modes of existence that stand in contrast to growth societies. In this article, I draw on scholarship in political ecology and environmental justice to show how degrowth perspectives are lived by highway protestors who might not self-identify with the terms 'degrowth', 'environmental justice' or 'political ecology' but whose activism sheds light on the negative social and environmental outcomes of growth-based development. I aim to contribute to the work of scholars who have sought to explore points of connection between the degrowth movement and others (see Escobar 2015), between degrowth and political ecology (see Paulson 2015) and degrowth and environmental justice more specifically (see Anguelovski 2015; Martinez-Alier 2012; and the work of Environmental Justice Organizations, Liabilities and Trade [EJOLT]).

In this article, I draw on news reports and on conversations I held in 2009 with protesters of the highway project, with activists in Chiapas, and with Chiapas State Government officials. These conversations, 25 in total, which were held in offices, homes, and community centers, occurred as highway construction commenced and opposition to it began to emerge. They revealed the government's growth-based discourse motivating attempts to build the highway, and clarified the source of opposition by those who found the highway project to be counter to their interests and destructive to their well-being. Later, in 2015 I turned to news reports about large-scale mobilizations against the project. They revealed that the source of the opposition was similar to that of the 2009 protests, and highlighted the links between NGOs, Zapatista communities, non-Zapatista Mayan and mestizo communities, academics, and religious figures who stood in solidarity. In what follows, I examine synergies between degrowth proponents and scholarship in environmental justice and political ecology so as to illuminate the motivations and experiences of activists in Chiapas. In doing so I hope to show one example of how degrowth thinking extends beyond what Correia (2012) identifies warily as its potential to become a form of bourgeois environmentalism where the privileged few comfortably choose to reduce their consumptive behaviors. 


\section{Neoliberalism, growth and highway development in Chiapas, Mexico}

Introduced in 2009, the contested San Cristóbal-Palenque highway project formed a key component of the Mexican Federal Government and Chiapas State Government's neoliberal growth-oriented development strategy in Chiapas - a strategy that has, over the past three decades, included attempts to expand resource extraction, tourism, and agribusiness in the state. Chiapas has long been seen by the Mexican state as a reserve of natural resources and agricultural goods needed to feed high demand in the industrial regions of central and northern Mexico (Fox and Haight 2010; Otero 1996). However, given its natural wealth and rich cultural tradition, Chiapas has also emerged as a popular destination for tourists looking for a unique environmental or cultural experience (van den Berghe 1995). Yet, despite fanfare over the economic potential of the state, resistance to development programs that have sought to exploit such wealth has emerged over the past twenty years. In this section I first contextualize road-building, including the San Cristóbal-Palenque highway project, within the broader political and economic motivations that have been mobilized by state officials to justify its pursuit in Chiapas. I then explore critiques of the mega-highway initiative that began in 2009 and reemerged in 2014 and led to its cancellation.

In Mexico, neoliberal reforms unfolded unevenly, and included the privatization of state-owned enterprises, the conversion of communal land into private property, and the production of industrial goods for export (Middlebrook 2003; Otero 1996). In rural Mexico, this transition involved a withdrawal of federal funding for rural development programs and a new focus on market-based development measures (Fox and Haight 2010). The nature of these reforms in Mexico varies regionally, but in Chiapas, has consisted of the expansion of agribusiness, resource extraction, and tourism.

In 2001, then president, Vicente Fox, announced the Plan Puebla-Panama (PPP), a regional development program designed to expand markets for primary commodities and tourism through widespread infrastructure development from the Mexican state of Puebla to Panama in Central America. Fox's development plan faced sharp opposition from the beginning by activists and NGOs in southern Mexico who viewed it as a mechanism for displacing Mayan people in the region so as to facilitate natural resource extraction and infrastructure development by transnational corporations (Zunino 2010). In the face of such criticism, the PPP subsequently disappeared from government rhetoric and many of its core projects were abandoned. Mariela Zunino notes, however, that the Plan's principles persisted through subsequent regional development initiatives such as the Proyecto Mesoamerica (PM) under Fox's successor, Felipe Calderon - an initiative that was supported with significant financial assistance from the U.S. Congress.

While the names of various government-led development programs have changed over time, the model under which such activities are pursued has been remarkably consistent: to remake rural Mexican space by integrating Mayan and mestizo communities into broader commercial markets for tourism and agribusiness, with the goal of attracting foreign investment and expanding GDP. As part of this strategy, the San CristóbalPalenque Highway project was seen as necessary for building a modern rural Chiapas defined by sustainable tourism and expanding agriculture that would be facilitated by efficient transportation routes and enhanced commerce in the region (Romero 2009). The Chiapas State Government argued that communities located along the path of the highway would be able to develop new commercial opportunities related to the production and sale of artisanal goods and the creation of ecotourism sites. The same government officials suggested that the highway would allow for the integration of local communities into broader markets, which would allow for improved access to employment opportunities. As one government official put it in 2009, "The San Cristóbal-Palenque Highway would cut the distance between the two most important tourist centers in Chiapas, which would allow for the detonation of development in this region of the state [Chiapas]" (Instituto de Comunicación Social 2009, emphasis by author). Thus, highway development was understood to be necessary for the success of the government's growth-oriented development vision in the region. This, however, is not new in Chiapas where road building has played an important historical role in capitalist modernization and state formation.

Road construction maintained a central role in Chiapas as one of the more important aspects of the modernization projects undertaken by late $19^{\text {th }}$ century governors of Mexico's southernmost state (Ficker and 
Connolly 1999). However, following the 1910 Mexican Revolution, roadway development initiatives were recast by the Mexican Federal Government in revolutionary terms projecting strong national pride. Epitomizing this perspective was President Calles (1928-1935) whose National Road Commission served as an important tool for the consolidation of the national territory and the integration of Mexico's disparate regions within the emerging post-revolutionary Mexican state (Waters 2006). This was particularly important in Chiapas, a state that had long been considered to be geographically and culturally distant in the national imagination and in the eyes of political elites in Mexico City.

In Chiapas, road building also served important post-revolutionary economic objectives. Here, roads were built in order to connect rural municipalities to newly created commercial agriculture centers in the interior lowlands near Ocosingo (Rus 1994). The underlying goal of these infrastructure projects was to encourage the movement of poor Mayan peasants who had been forcefully displaced from their land during the presidency of Porfirio Diaz (1876-1911) to work as migrant laborers on commercial agriculture plantations. Rus (1994) notes that as a result of these efforts, Chiapas became Mexico's largest producer of coffee, beans, and corn for national consumption and one of the top three producers of sugar, rice, cacao, tropical fruits and cotton. Importantly, however, the link between road building and economic growth depended on the labor of the state's exploited Mayan population, a connection that has not been forgotten in contemporary protests of the San Cristóbal-Palenque highway project.

Despite strong government support for the San Cristóbal-Palenque highway project, local opposition to it quickly became apparent in Chiapas. Protesters in the southernmost state, like their counterparts in eastern Oaxaca who also protested the building of a mega-highway, albeit in the Isthmus of Tehuantepec, argued that it would facilitate aggressive resource extraction and environmental destruction, and present a series of dangers to communities located along the highway's proposed path. Such perspectives have been echoed by degrowth proponents such as Latouche (2009: 38) who suggested that "the tourist industry has transformed legitimate curiosity and educational inquisitiveness into a consumerist consumption that destroys the environment, culture and social fabric of the 'target' countries."

Protests of the highway project led by communities in the southernmost state and supported by activist NGOs, came to a head in 2009. They included communities just outside the city of San Cristóbal de las Casas and along the path of the highway. Communities staged marches and formed road blockades in defiance of strong government pressure to let the highway pass. Explaining the motivation for the opposition, one group of community representatives from the municipality of Chilón near Palenque said in an interview:

The government wants to build the road so that it can access and control the state's natural resources. For us, the road represents a threat - a threat to our resources, to our forests and our farmland. We do not need the highway. We do not use highways nor do we have the means to use them. The highway will only allow for the exploitation of our resources. (Interview August 1, 2009)

Protesters near San Cristóbal de las Casas also posted signs such as the one portrayed in Figure 1, which read as follows: "Ejidos Flores Magón and Mitzitón will not permit the construction of the highway through our territory in accord with the ejidatarios. Whoever tries to do so places themselves in the hands of the community, whoever they may be." Signs such as this illustrated an attempt by concerned communities to disrupt enhanced connectivity through highway construction so as to promote local needs and economies that better reflected the concerns of groups such as the Chilón protesters rather than those of transnational actors.

Due to the tension produced by opposition movements, the Mexican Federal Government and Chiapas State Government eventually backed down, cancelling the project in 2009, and arguing that it is the "pueblo that gives orders and the government's duty to obey" (El Heraldo de Chiapas 2009). In the end, the cancellation of the project was seen by opposition actors as a strong public rebuttal of the Mexican state's attempts to advance the infrastructure needed to pursue capitalist economic growth in the region. The cancellation, however, was not permanent. 


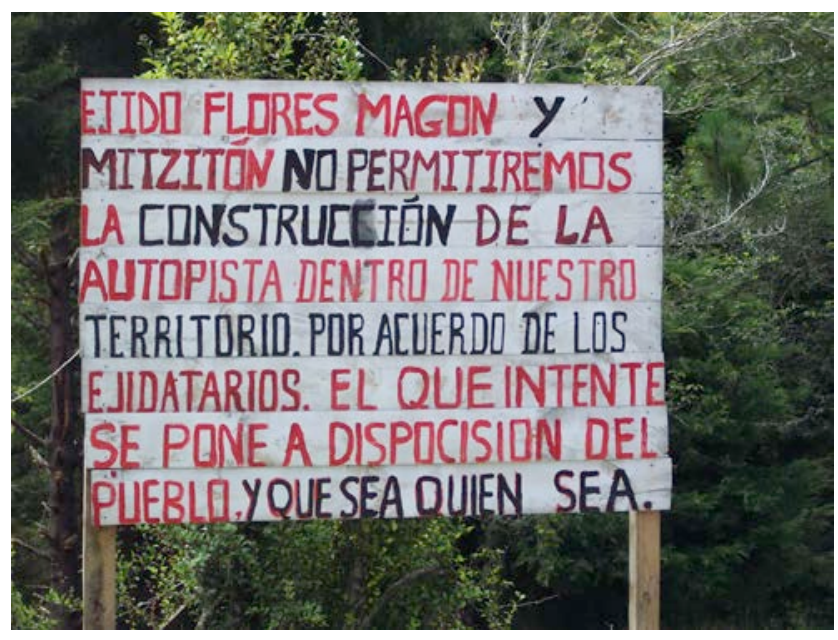

Figure 1: Sign posted outside community in protest of highway construction. Source: Author

In 2014, under new leadership, the state government re-initiated the highway project, promising a greater degree of transparency and assuring that community interests would be protected. However, protests emerged again in 2014 and 2015, this time with greater force and with broader participation among a closely connected network of civil organizations in the region (referred to by Rocheleau [2015] as 'rhizomatic' in nature). As was the case with the previous opposition, this network of activists also led to the cancellation of the second iteration of the project by early August of 2015. The key moment in the protests came when, on September 17, 2014, more than 2,000 people from over 70 communities gathered to denounce the highway initiative, with the support of the Movement in Defense of Life and Territory (Movimiento en Defensa de la Vida y el Territorio) (Bellinghausen 2014a; 2014b). The Movement provided an important component of the interconnected set of actors opposing the project, and included oppositional communities, allied NGOs, activists, and academics in the state. The main argument of this broad opposition reflected that of 2009: that the tourism and agricultural growth potential of the highway project would be destructive rather than beneficial, posing a threat to the welfare of the natural environment and communities across the state. As the 2,740 signatories to a September 17, 2014 declaration, the Declaration of Laguna Suyul, put it:

Mother Earth is our ancient gift that, from generation to generation, our grandfathers and grandmothers have cared for and defended. They protected it. Now it is our turn to take care of it and defend it, if necessary, with our lives. The natural environment, the tissue and veins of Mother Earth - rivers, lakes, pools of water, mountains, trees, caves and hills. We will defend the life of the animals, sacred places, the ecosystem of Mother Nature and human life. The Mother is not for sale and it has no price. (Declaración 2014)

Here, protesters clearly articulated their opposition to the continued sale and unconstrained destruction of the natural environment, noting, as with the image above, their willingness to resist attempts to do so with their lives, if needed.

The nature of the argument presented by those opposing the highway initiative in Chiapas resonates with the concerns of degrowth proponents. Namely, anti-highway activists argued that growth was destructive rather than beneficial, and that it would destroy the natural environment, leading to social and environmental devastation. Importantly, however, closer examination reveals several additional and notable characteristics of the specific case. First, opposition in Chiapas not only articulated an anti-growth argument, but did so by 
locating concerns about the highway project within a broader awareness of Mayan rights in the face of the Mexican state, a long-time pillar of the Zapatista movement. As the signatories to the Declaration argued:

We will not permit them [the Mexican state] to continue violating our rights. We demand that they respect us in accordance with Convention 169 of the ILO (International Labor Organization) and the United Nations Declaration on the Rights of Indigenous Peoples... that defends the collective and individual rights of the communities, especially their rights to land, goods, vital resources, territory and cultural resources, identity and language, employment, health, education, and to freely determine their political policies and economic development.

Here it becomes clear that shifting global political economies toward producing and consuming less, although a shared objective with degrowth, is, as Anguelovski (2015: 36) notes, "not enough." The source of the highway protests extended well beyond worries about expanding production and consumption, reflecting additional issues of power, history and Mayan rights to - and relationships with - the natural environment. However, the above statement also demonstrates concerns about distribution, particularly the distribution of goods, employment opportunities, health and education. Such concerns about distributional justice, which will be discussed in greater detail below, are historically rooted, and are motivated by concerns over projects that, while funded by national and global actors such as the World Bank, stand to support the well-being of the few while generating local environmental destruction.

In order to examine links between the highway opposition in Chiapas and degrowth proponents, I draw on work in environmental justice and political ecology. The next section traces the intellectual history of each and highlights the advances made by increasing synergy between them.

\section{Environmental justice and political ecology}

Environmental justice work within political ecology provides key points of emphasis that parallel the concerns of anti-highway protesters in Chiapas. These include a focus on distributional and procedural justice and the recognition that justice claims are often rooted in a broader socio-historical context that includes diverse actors who are connected across scales. Yet, while political ecology and environmental justice may illuminate common ground with movements such as the anti-development protests in Chiapas, environmental justice and political ecology have distinct origins and traditions, and have joined together more explicitly in the past fifteen years (Holifield 2015). As Holifield notes, it was a melding that facilitated the broadening of environmental justice work to include environmental concerns in the Global South, while also infusing it with a new emphasis on ethnographic methods, radical political economy, and critical social theory and political theory - a combined perspective that illuminates the broad set of concerns held by the highway opposition in southern Mexico. In this section I briefly outline this history so as to lay the groundwork for imagining a degrowth-environmental justice framework.

Environmental justice movements originated in the United States in the late 1970s and early 1980s as an attempt to raise awareness about and respond to the negative impacts of environmental conditions on human health. Well-known early environmental justice concerns were oriented, for instance, around housing in Love Canal, New York and unequal exposure to landfill toxins in Warren County, North Carolina. Since then environmental justice has expanded to include issues such as the effects of weapons testing in the Southwest United States and its toxic impacts on Native American and non-Native American communities (see Masco 2011). Moreover, recent environmental justice work examines the gendered experience of environmental degradation, the role of women in making justice claims (see Ornelas 2011), and the impacts of climate change on minority communities. In these cases, environmental justice movements have emerged as community organizers, lawyers, academics, activists, and scientists have attempted to identify sources of environmental injustice, to hold perpetrators accountable, to gain compensation for victims, and to work with communities to empower them to respond to violations.

The literature highlights two key issues assessed within environmental justice work - distributional and procedural justice - both of which must be taken into consideration to understand how violations occur and why environmental justice movements emerge. Distributional justice refers to the disproportionate 
exposure to environmental threats, usually by minority groups. However, as Anguelovski (2015) points out, distributional injustice not only refers to the uneven distribution of "bads" but of "goods" as well. In this sense, distributional injustice may be seen in unequal exposure to waste (the distribution of "bads") in minority communities, but may also refer to the general absence of healthy waste disposal programs or schools and other services in those same communities. Procedural injustice, on the other hand, refers to the deliberate exclusion of certain groups of people from participation in the political decision making process associated with locating certain environmental threats (Perreault 2008; Wolford 2008). The voices that are heard are often those of a privileged segment of society that is able to successfully oppose environmentally destructive development programs - e.g. the building of a waste site or a nuclear energy plant - out of concern for the negative health, environmental, or social impacts they may pose for themselves and their communities.

In literature on rural livelihoods, concerns about distributional justice have been discussed, particularly in relation to peasant economies. Work on peasant economies is broad, although a significant portion of the literature is centered on the relationship between distribution and exploitation (particularly in the context of expanding capitalist social relations). In his seminal work, James Scott suggested that according to some, exploitation consists, in part, of "an unfair distribution of effort and rewards" wherein peasants receive disproportionately fewer rewards for their labor than do the owners of the means of production (1976: 58). In Chiapas, such exploitative labor arrangements were common during the rule of Porfirio Diaz when debt peonage was used by large landowners to coerce the state's marginalized Mayan populous into working within the growing agricultural export economy (Washbrook 2006). Concerns about distributional justice, albeit of a slightly different type, persist in the Chiapaneco countryside where, Solis (2005) notes, fewer resources have been invested by the state as compared to the urban centers of central and northern Mexico. According to Solis, this unequal distribution of capital has contributed to low agricultural productivity in Chiapas and to the migration of young people to northern Mexico and the U.S. Importantly, the victims of distributional injustice are also often the victims of procedural injustice as their concerns have often been ignored in the creation of economic policies.

Unlike environmental justice, political ecology work originated not as a movement, but rather, as an academic field, combining critical political economy with ecology to explore transnational issues of resource governance and development. More recently, some thinkers working in political ecology adopted a poststructural lens to provide new theorizations of nature and human-environment relations. Key areas of analysis within political ecology are varied, and include issues of land degradation and deforestation, the production of nature through waste management practices and international 'trash trading' (Moore 2011), the dispossession of underrepresented communities through urban greening programs in India (Ghertner 2011), and the environmental politics of global health (Biehl 2011). Like environmental justice work, political ecology has focused on issues of injustice in the context of human-environment relations. However, while environmental justice was developed largely in the Global North, the first decades of political ecology were centered on the Global South. Moreover, from the start, political ecologists have embraced critical social theory, critical political economy, the use of ethnographic methods, and a recognition that injustice is linked to broader processes and sets of actors that are situated historically and connected across space.

While environmental justice and political ecology originated in divergent settings, in the late 1990s and early 2000s the two began to intersect, extending the mode of analysis and range of considerations for environmental justice scholars and political ecologists. This merger featured a shift in geographic focus for both as political ecologists began to look toward the Global North, and as environmental justice advocates in the Global North began to expand their vision to the Global South (Holifield 2015). The outcome, Holifield notes, was transformative as environmental justice scholarship began to embrace the use of qualitative methods, to engage radical political economy, and to draw on critical social theory and political theory. Moreover, key components of political ecological work - namely considerations of scale and a broader historical context - also began to inform environmental justice.

Evidence of expanded environmental justice work can be seen in studies of a variety of environmental topics. These include conflicts over natural resources in the Global South oriented around mining, deforestation and even climate change mitigation programs such as REDD+ (Reducing Emissions from 
Deforestation and Forest Degradation). However, others have also examined environmental justice by exploring relationships of indigenous groups to the natural environment. Watts (2000), for instance, explores justice claims by the Ogoni in Nigeria in the face of oil extraction, while Schroeder (2000) highlights issues of resource extraction and environmental justice in Indonesia. In Latin America, political ecological and environmental justice work has explored state restructuring in Bolivia (Perreault 2008) and agricultural development in Brazil (Wolford 2008), showing how actors at multiple scales re-shape human-environment relations in an unequal manner. Moreover, as this work demonstrates, justice claims and protests cannot be fully understood without analyzing them within their broader socio-historical context. In the next section, I turn back to the case of the San Cristóbal-Palenque highway project, drawing on environmental justice work in political ecology to further explore the concerns of the Chiapaneco protesters.

\section{Political ecology, environmental justice and the San Cristóbal-Palenque highway}

Highway protesters in Chiapas argued that despite the claims of government officials the San Cristóbal-Palenque highway project would bring social and environmental destruction - a point shared by degrowth proponents in their concerns about growth-based development. Yet, this opposition was also informed by a broad set of additional factors commonly considered within environmental justice work in political ecology, including concerns about procedural and distributional injustice and the broad history of policies carried out by the Mexican state, that have disenfranchised local communities.

In 2009, conversations with leaders of communities along the path of the highway revealed concerns about procedural justice as many noted that they felt excluded from participation in the decision making process about whether or not the highway project would be of benefit to their communities. In one case, leaders in Mitzitón, a community near San Cristóbal de las Casas, noted in interviews that when initial construction began on the project they had travelled to the state capital, Tuxtla Gutierrez, to voice their concerns. Their efforts, they explained, were in vain as government officials either refused to listen to them or attempted to placate them with empty promises. By 2014, the sense of exclusion grew as protesters, now more organized, began to vocalize their concerns in mobilizations and news reports. By this point, however, activists were also voicing distributional concerns.

In a November 2014 march that included an estimated 21,000 people from municipalities along the highway's proposed path, participants described distributional concerns related to the highway project. According to Henríquez's (2014) reporting on the event, they argued:

All the communities and municipalities located along the path of the highway live in extreme poverty. And yet, it is a joke to suggest that the highway will improve our lives.

Continuing, they said:

... the highway will bring with it other customs, will lead to elevated alcoholism and drug sales and will not benefit the great majority of the community, but rather, the large companies and business people, and perhaps in a few cases, some retailers.

Finally, they forcefully concluded:

If the federal and state governments really want to support the communities in poverty as they say they do, we ask that the billions of pesos dedicated to this project be used to finish the more than 40 hospitals and clinics that, because of corruption, were left unfinished during the last term [of the governor of the state of Chiapas]. We ask that they pave the hundreds of rural roads that are in terrible condition so that we may transport the sick and sell our merchandise. 
These comments highlight the fact that for communities located along the road's path, the project represented an unequal distribution of "bads" wrought by the potentially destructive outcomes of highway development. However, they also reflect an uneven distribution of "goods" whereby much needed resources were spent on a destructive highway program designed to benefit transnational elites, money that could have been spent on lacking services for local communities. Importantly, however, as the above quotes indicate, the referenced distributional and procedural injustices emerged not simply through local social relations, but as an outcome of the efforts of actors who operate across multiple scales.

In recognition of the spatial character of procedural and distributional injustices in development, highway protesters argued that the project would only benefit "large companies and business people" rather than local communities (Henríquez 2014). To explain the local impacts of transnational activities such as these, political ecologists employ a 'chains of explanation' approach (see Blaikie and Brookfield 1987; Robbins 2004; Watts and Peet 2004) that emphasizes the connected nature of actors, policies, and actions at multiple scales, and the impacts of such interactions in producing inequality and environmental degradation in local contexts. Recognition of the scaled nature of the actors and activities that comprise transnational development initiatives reveal the complexity of such projects, including the dynamic power relations involved (Watts 2000). However, in the case of the San Cristóbal-Palenque project, these power dynamics were also connected to a broader social history that inspired the related protests.

The historical dimensions of the highway protests are especially clear among one segment of the opposition, pro-Zapatista communities. The Zapatistas, who had been organizing since the 1980s, argued that development in Chiapas had too long been focused on exploiting the state's wealth at the expense of its Mayan population. As then Subcomandante Marcos (1994) of the Zapatistas put it:

One million Indigenous people live in these lands and share a disorienting nightmare with mestizos and ladinos: their only option, 500 years after the "Meeting of Two Worlds," is to die of poverty or repression. The programs to improve the conditions of poverty, a small bit of social democracy which the Mexican state throws about and which, under the regime of Salinas de Gortari carries the name PRONASO, are a joke that brings bloody tears to those who live under the rain and sun.

Marcos' quote highlights the fact that issues of distributional and procedural injustice do not simply emerge as an outcome of the policies and actions of contemporary actors operating across scales, but have a longer place in history dating back to roadway building during the regime of Porfirio Diaz and even to European colonialism.

\section{Conclusion}

Degrowth movements are an attempt to imagine and implement a future defined not by ever-expanding production and consumption, but by alternatives that decolonize collective thinking about what it means to live well. Originating in France and expanding slowly to Spain, Latin America and the U.S., the term has gained traction as a social movement, a slogan, and even an area of study within academia as conferences, special issues, and edited volumes begin to appear. Latouche (2009) suggests that alternatives to a growth society may be developed by letting silenced voices be heard, and by building allegiances with activists around the world. The goal of degrowth proponents toward establishing conditions of inclusivity is attractive given the diversity of environmental and anti-development perspectives around the world - ideas that are shared by people whose voices often go unheard.

In Chiapas, certain voices have long been excluded from the decision-making processes linked to development in the region. In 2009 and 2014 activists who live degrowth in their daily activities and in their activism, spoke out forcefully against the San Cristóbal-Palenque highway project. Their concerns resonated with those of degrowth proponents who suggest that growth is destructive rather than beneficial by arguing that the highway project would destroy the natural environment and create social division. However, their protests were also motivated by an additional concern related to the distribution of resources. Highway 
protesters argued, for instance, that the highway project would disproportionately benefit government and private sector actors, and that what is needed in order to effectively address the interests of the neediest in the state is not a new highway, as much as greater access to social services, schools and health clinics. Degrowth thinking combined with environmental justice perspectives not only help the problems of growth-oriented objectives become clear, but so too the distributional shortcomings that often accompany such initiatives.

A combined environmental justice, political ecology and degrowth approach has allowed a more integral understanding of motivations behind the activism of Chiapaneco protestors. It is an approach that speaks to the ability of degrowth proponents to act in solidarity with a broad set of actors whose concerns are rooted in local histories and experiences of oppression.

\section{References}

Anguelovski, I. 2015. Environmental justice. In G. D'Alisa, F. Demaria, and G. Kallis (eds.). Degrowth: a vocabulary for a new era. New York: Routledge. Pp. 33-36.

Bellinghausen, H. 2014a. Rechazan indígenas el paso de autopista por sus comunidades. [accessed July 15 2015]. http://www.jornada.unam.mx/2014/09/18/index.php?section=politica\&article=014n1pol

Bellinghausen, H. 2014b. Para los niños que vienen del futuro, no para nosotros. [accessed July 15 2015]. http://www.jornada.unam.mx/2014/10/11/oja-ninos.html

Biehl, J. 2011. When people come first: beyond technical and theoretical quick-fixes in global health. In R. Peet, P. Robbins and M.J. Watts (eds.) Global political ecology. New York: Routledge. Pp. 100-130. $\underline{\text { Scribd }}$

Blaikie, P.M. and H.C. Brookfield. 1987. Land degradation and society. London: Methuen.

Correia, D. 2012. Degrowth, American style: no impact man and bourgeois primitivism. Capitalism, Nature Socialism 23(1): 105-118.

Declaración de la Laguna Suyul. 2014. [accessed March 15 2017]. http://www.alainet.org/es/active/77239

El Heraldo de Chiapas. 2009. Inversión histórica para los pueblos indígenas de Chiapas en 2010. [Accessed December 28 2009]. http://www.oem.com.mx/elheraldodechiapas/notas/n1456954.htm.

Escobar, A. 2015. Degrowth, postdevelopment, and transitions: a preliminary conversation. Sustainability Science 10(3): 451-462.

Ficker, S.K. and P. Connolly. 1999. Ferrocarriles y obras públicas. México: Instituto de Investigaciones.

Fox, J. and L. Haight. 2010. Subsidios para la desigualdad. Washington, DC: Woodrow Wilson International Center for Scholars.

Ghertner, D.A. 2011. Green evictions: environmental discourses of a "slum-free" Delhi. In R. Peet, P. Robbins and M.J. Watts (eds.) Global political ecology. New York: Routledge. Pp.145-166.

Henríquez, E. 2014. Marchcan en Chiapas contra autopista San Cristóbal-Palenque. [Accessed July 15 2015]. http://www.jornada.unam.mx/ultimas/2014/11/25/marchan-en-chiapas-contra-megaproyecto-de-laautopista-san-Cristóbal-palenque-1511.html

Holifield, R. 2015. Environmental justice and political ecology. In T. Perreault, G. Bridge and J. McCarthy (eds.) The Routledge handbook of political ecology. New York: Routledge. Pp. 585-597.

Instituto de Comunicación Social. 2009. Inversión histórica para los pueblos indígenas de Chiapas en 2010, anuncia Juan Sabines. In Instituto de Comunicación Social (ed.). Mexico City, Mexico.

Kallis, G., F. Demaria and G. D'Alisa. 2015. Introduction: degrowth. In G. D'Alisa, F. Demaria and G Kallis (eds.) Degrowth: a vocabulary for a new era. New York: Routledge. Pp. 1-18.

Latouche, S. 2009. Farewell to growth. Malden: Polity Press.

Latouche, S. 2010. Degrowth. Journal of Cleaner Production 18: 519-522.

Latouche, S. 2012. Can the left escape economism? Capitalism, Nature Socialism 23(1): 74-78.

Marcos. 1994. The southeast in two winds - a storm and a prophecy. In Autonomedia (ed.) Zapatistas! documents of the new Mexican revolution. Brooklyn: Autonomedia. 
Martínez-Alier, J. 2012. Environmental justice and economic degrowth: an alliance between two movements. Capitalism Nature Socialism 23(1): 51-73.

Masco, J. 2011. Mutant ecologies: radioactive life in a post-Cold War New Mexico. In R. Peet, P. Robbins and M.J. Watts (eds.) Global political ecology. New York: Routledge. Pp. 285-304.

Middlebrook, K. and E. Zepeda. 2003. On the political economy of Mexican development policy. In K. Middlebrook and E Zepeda (eds.) Confronting development: assessing Mexico's economic and social policy challenges. Stanford, CA: Stanford University Press. Pp. 3-54.

Moore, S. 2011. Global garbage: waste, trash trading and local garbage politics. In R. Peet, P. Robbins and M.J. Watts (eds.) Global political ecology. New York: Routledge. Pp. 133-144.

Ornelas, R. 2011. Water and the Indigenous Women's Leadership Project. Journal of Research on Women and Gender 2(1): 111-134.

Otero, G. 1996. Neoliberal reform and politics in Mexico: an overview. In G. Otero (ed.) Neoliberalism revisited: economic restructuring and Mexico's political future. Boulder: Westview Press. Pp. 1-26.

Paulson, S. 2015. Political ecology. In G. D'Alisa, F. Demaria, and G Kallis (eds.) Degrowth: a vocabulary for a new era. New York: Routledge. Pp. 45-58.

Paulson, S. 2017. Degrowth: culture, power and change. Journal of Political Ecology 24: 425-448.

Perreault, T. 2008. Popular protest and unpopular policies: state restructuring, resource conflict, and social justice in Bolivia. In D.V. Carruthers (ed.) Environmental justice in Latin America: problems, promise, and practice. Cambridge: MIT Press. Pp. 239-262.

Rocheleau, D. 2015. Networked, rooted and territorial: green grabbing and resistance in Chiapas. The Journal of Peasant Studies 42(3-4): 695-723. Researchgate

Robbins, P. 2004. Political ecology. Oxford: Blackwell Publishing.

Romero, J. 2009. La autopista San Cristóbal-Palenque, la espina dorsal del CIPP: sigilo y destrucción violenta. San Cristóbal de las Casas, Mexico: Centro de Investigaciones Económicas y Políticas de Acción Comunitaria (CIEPAC).

Rus, J. 1994. The 'comunidad revolucionario': the subversion of native government in highland Chiapas, 1936-1968. In. G.M. Joseph and D. Nugent (eds.) Everyday forms of state formation: revolution and the negotiation of rule in Mexico. Durham, NC: Duke University Press. Pp. 265-300.

Schroeder, R.A. 2000. Beyond distributive justice: resource extraction and environmental justice in the tropics. In C. Zerner (ed.) People, plants, and justice: the politics of nature conservation. New York: Columbia University Press. Pp. 52-66.

Scott, J. 1976. The moral economy of the peasant: rebellion and subsistence in Southeast Asia. New Haven: Yale University Press. intro

Solis, D.V. 2005. Rural Chiapas ten years after the armed uprising of 1994: an economic overview. The Journal of Peasant Studies 32(3-4): 461-483.

van den Berghe, P. 1995. Marketing Mayas: ethnic tourism promotion in Mexico. Annals of Tourism Research 22(3): 568-588.

Washbrook, S. 2006. Una esclavitud simulada: debt peonage in the state of Chiapas, Mexico, 1876-1911. The Journal of Peasant Studies 33(3): 367-412.

Waters, W. 2006. Remapping identities: road construction and nation building in post-revolutionary Mexico. In M.K. Vaughan and S.E. Lewis (eds.) The eagle and the virgin: nation and cultural revolution in Mexico, 1920-1940. Durham, NC: Duke University Press. Pp. 221-242.

Watts, M.J. 2000. Contested communities, malignant markets, and gilded governance: justice, resource extraction, and conservation in the tropics. In C. Zerner (ed.) People, plants and justice: the politics of nature conservation. New York: Columbia University Press. Pp. 21-51.

Watts M.J. and R. Peet. 2004 [1996]. Liberating political ecologies. In R. Peet and M.J. Watts (eds.) Liberation ecologies: environment, development, social movements. New York: Routledge. Pp. 3-47. 
Wolford, W. 2008. Environmental justice and agricultural development in the Brazilian cerrado. In D.V. Carruthers (ed.) Environmental justice in Latin America: problems, promise, and practice. Cambridge: MIT Press. Pp. 213-238.

Zunino, M. 2010. Integración para el despojo: el Proyecto Mesoamérica. San Cristóbal de las Casas, Mexico: Centro de Investigaciones Económicas y Políticas de Acción Comunitaria (CIEPAC). 